\title{
Gender-based Responses to Peer Reviews in Academic Writing
}

\author{
Listyani \\ Satya Wacana Christian University, Salatiga, Indonesia
}

\begin{abstract}
We are living in a digital era in which everybody who is not participating will be left behind. Yes, that is true. We are all chased by the rapid changes of this era, and we are running faster and faster to catch up with the latest technology. It seems as if we are all haunted to go deeper and deeper into the "tunnel of the digital era". The same thing happens in the world of education. However, if we notice more closely, there are still some aspects that can be done directly without necessitating the use of technology. One example is studentstudent direct interactions. Technology can be used to facilitate peer assessments, not replace student-student interactions. One central research question to be answered in this paper is: What are male and female Indonesian students' points of views towards peer reviews? Despite all the sophisticated technology we are all exposed to in this era, peer feedback should still be done directly with real, face-to-face communication in a classroom setting. Indirect online communication or chatting through social media may cause a misunderstanding and misinterpretation of one's ideas. Data for this study was taken from 39 students' opinions in their journals. They were Academic Writing class students of the English Department of UKSW Indonesia, in Semester II, 2015-2016. Most students stated that direct and interactive face-to-face communication is still needed. It proves that digitation cannot replace everything. Real communication with real peers in the real - not cyber - world can enhance successful learning. The findings also reveal that differences were found between male and female students' reactions or perceptions towards peer reviews.
\end{abstract}

Index Terms - peer reviews, male and female, academic writing, points of view

\section{INTRODUCTION}

Some underlying theories which are used for the foundation of this paper are discussed below.

\section{A. Gender Differences}

Some say that men are from Mars, while women are from Venus. The parable may be right, considering the physical and psychological differences between those two genders. Before it is discussed further, some concepts about gender are discussed below.

Hyde and Durio (2005), in Wehr-Flowers (2006), distinguished between the concept of gender as a person variable or stimulus variable. As a person variable, gender is thought of as a characteristic of the person. In contrast, psychological research conceptualizes gender as a person variable. In sociological research, this is different. Gender is conceptualized as a stimulus variable where someone's gender affects any information and cues which are received by others. This, in turn, will influence their motivation or self-efficacy. In social-psychological theories, the concept of self-efficacy is "domain-specific", and this accentuates the importance of socializers in the development of competence.

There are several differences between men's and women's thinking patterns. One of them is that men are better at certain types of task-specific activities and analytical thinking, while women are superior in multitasking (Brown, 2017). Another difference is that men in general are more independent than women. On the other hand, women become distressed if they do not share with their friends. They need to confide, even if their friends cannot provide any solutions. This is a very popular point of conflict where women often share about a problem with the intention of only sharing it. A woman often becomes surprised by the man's intention to provide a solution to the problem. The next difference is that men tend to be decision makers, while women consider every single decision that they have to make (2knowmyself.com).

The fact that women are more subject/ prone to stress is perhaps due to men's brains' ability to synthesize serotonin far more quickly than their female counterparts. Women can get depressed more easily. Sydelnykov (2015) further stated that women are also far more likely to suffer from a post-traumatic stress disorder after a traumatizing event.

Women are consistently rated highly for being inherent to the feminine gender role by providing a friendly classroom environment (Langbein, 1994, as cited in Carson, 2001). From a piece of research in music education, Wehr-Flowers (2006), as cited from Feldman and Gardner (1998), mentioned that "Creative individuals need distance from their peers, tend to avoid interpersonal contact, and tend to resist societal demands. In contrast, adolescent females tend to be concerned with popularity and social groups and want to fit into society-defined roles". Wehr-Flowers emphasized that women have the tendency to be concerned about fame and socialization, and they always want to fit into roles which are defined by the society. 
Citing from Ellen Rowe (1995), Wehr-Flowers further stated that "Young men are encouraged to seek attention, whereas women are not given the tools of confidence or self-esteem to handle such attention." Men seem to be destined to be able to solve problems with confidence and self-esteem; a condition which is so different from women.

Frederickson (2000) in Wehr-Flowers (2006) also suggested that some women and girls choose not to participate in the classroom not because they are not able to, but because of social politeness and a fear of breaking norms. This is called female silence. Adolescent girls are particularly interested in making and keeping friends.

Kemp (1996), as cited by Wehr-Flowers (2006), also reported that men score higher on measures of introversion and some measures of independence. Their female counterparts score higher in measures of sensitivity and anxiety in general populations.

In the world of education, however, the same opportunities should be given to all students, both male and female. Male domination should not exist anymore. This was also stated by Jati (2017). He confirmed that, "The digital world and "non-digital" world are equal in terms of justice and equality. Everyone, anybody will have the same opportunity to take part." Gender issues should not become a big problem in the world of education.

\section{B. Gender Differences in Language Learning}

No one denies the fact that men and women are created differently. One aspect of life is language learning. Some research on it has been done. Tucker (2013), for example, conducted research on gender bias and gender differences in peer assessments. He used 1,500 participants from two universities. The findings show that there was an absence of gender bias in six case studies.

\section{Digital Era}

This is true that we are all living in an era where people are competing. According to Mark Surman, the Executive Director of the Mozilla Foundation, as cited by Gurney (2013), skills in digital literacy are as important as learning to read and write. Mark further stated, "If you want your kids to be smart and safe in the digital world - whether that is in school or out of school - having them understand how the technology works, how copyright works, how identity works, is way more important than whether they have access to information or not" (Gurney, 2013). It means that beyond students' skillfulness and intelligence in using technology, there are still many other things to consider. Ethics in writing, collaborative work with peer students, for example, and understanding a process of how something is done are more important than mastering a particular kind of technology itself.

Crowley (2014) also reaffirmed this matter. Citing from the Department of Education in New York, Crowley stated that "Digitally literate people are those who can use technology strategically to find and evaluate information, connect and collaborate with others, produce and share original content, and use the Internet and technology tools to achieve many academic, professional, and personal goals." Technology is only a means. It is not everything in achieving the goals of the teaching learning process. According to Soefijanto (2015), Indonesia ranks in the middle in terms of technological advancement, in the Southeast Asian region.

Zacharias (2017), from Miami University, also stated a similar thing. Besides human resources - in this case teachers - that need improving, more funds are needed for the improvement of the infrastructure, material development, and teacher training as well.

If it means all teaching and learning are conducted using the aid of technology, then, I think the secondary level of education in Indonesia is far from ready because the preparation to digitize education is multi-dimensional. Teachers need to be educated in using, utilizing, and evaluating technology, among others. There also needs to be money for the infrastructure (buying good computers, having good Internet access, and having good IT support) of the school. Teaching materials also need to be adapted to allow for the teacher and students to conduct teaching and learning digitally. Most of all, students need to be trained on how to learn differently because being students in a digital classroom is significantly different from a traditional classroom. (Zacharias, 2017).

A similar opinion was espoused from Jati, a lecturer at the Institute of Technology, Bandung (ITB). He stated that in general, Indonesia is not ready yet to face the digital era.

Most of the teaching and learning materials are still in the form of paper and books, even in big cities. The availability of digital materials is very rare or expensive. The infrastructure is not ready (only some schools in big cities are ready). Even some schools in remote area do not have sufficient electricity. The schools' leaders, headmasters, and teachers are not prepared for digitation yet. Not enough training is given to schools' leaders. Digitation needs a huge budget (I do not think that the government is ready in terms of budget). (Jati, 2017).

One area that can never be replaced by technology is direct interactions between teacher-students, between a student and his/her peers, and among students. In direct interactions, there are many things that can be learned besides exchanging ideas and opinions. Students also learn soft skills like courtesy in expressing ideas, appreciating and accepting others' opinions, expressing disagreements without offending others, or disagreeing in an appropriate manner.

As stated by McNutt (2016), society is losing to apathy. Less and less people have sympathy. People are getting dumber. "We're losing society to apathy, to digital technology, the people who care about nobody else but themselves. They share every little detail of their stupid lives online as if the world even gives a damn ... digital technology is getting smarter and society is getting dumber," Mandy whispered in a voice filled with disbelief. "Society is ... it's 
slipping away." Good direct relationships within the society, even within the family may gradually be replaced by technology. That is what McNutt means by the statement "Society is losing apathy."

\section{Peer Reviews}

Student evaluations so far are seen as the most common method used to assess teaching performance during classroom instruction. This method is perceived as reliable and valid for assessing teaching effectiveness. However, there is a potential for evaluation bias that has been noted in literature (Wellein et al., 2009). In Wellein's article, it is revealed that the researchers found a strong positive correlation between the mean course evaluation scores and the students' actual and expected grades. This suggests that there is a big possibility for students to positively evaluate faculty members who award them with higher grades. In other words, student evaluations can be biased based on the benefits that they get. That is the case of student evaluations on faculty members' or lecturers' overall performance.

In dealing with students' evaluations of their peer students' works, Kennedy (2005) mentioned that peer assessment refers to "any of a variety of approaches where group members are required to evaluate other members of the group on their relative contributions to a project. The group mark awarded for the collaborative product can then be distributed accordingly". Ur (1999, p. 171) also supported this idea. She stated that one possible solution for correcting written work is by asking students to correct and also edit each other's writing.

Peer correction surprisingly can be a technique which is useful and time-saving for teachers. This can also be a great exercise for critical reading, language accuracy, as well as essay analysis for students. Ur further claims that this activity - peer assessment - can be a kind of substitute measure for first-draft reading. Students do the reviews or corrections of the first drafts. They can give comments both on the content as well as the language and organization. Teachers then need to work on the students' final drafts.

Students also learn valuable lessons in this activity. That is, they learn about trust, willingness to help, inclination to accept criticism, and also readiness to maintain good relationships, although they have to be critical of each other's works. Classes where there are opportunities for students to interact with each other help students to construct knowledge effectively. Emphasizing the collaborative and cooperative nature of scientific work will make students share their responsibility for learning with each other. They can also discuss different understandings, and hence shape the direction of the class (Carleton.Edu, 2017).

In the context of this research, peer assessment refers to an assignment given to the Academic Writing students using an instrument called a peer assessment form. Students were assigned this task where they were required to assess other members of a group in their class. Brown (2001, p.413), as cited from Brown and Hudson (1998), mentions the advantages of peer assessment. Among others, the advantages are speed, students' involvement, students' autonomy, and students' increased motivation, since they are all in the process of learning. There is only one disadvantage, according to Brown: the subjectivity of the students. One way to avoid or handle subjectivity is by assigning random peer assessment, meaning that students cannot choose who their partners are. Another solution is by having what is called as blind reviews. Teachers distribute essays without students' names on them. Hence, students will not know whose work they are assessing.

Penaflorida (2001) added that when students respond to each other's works, they can be excellent in providing one thing that writers need most, that is, being an audience. Students become an audience for each other in this activity. This practice is challenging, both for good and low achievers. Good achievers will try their best to help their peer students, while the low achievers will also put forth their best efforts to share with their intelligent peers. Take and give happens in this activity.

About the advantages of peer assessment, Bostock (2017) stated, "Student assessment of other students' works, both formative and summative, has many potential benefits to learning for the assessor and the assesse. It encourages student autonomy and higher order thinking skills. " Peer assessment can encourage learner autonomy as well as incite better critical thinking skills, as students have to think clearly in criticizing and giving suggestions for their friends' works. The aim of peer assessment is thus to improve the quality of learning and empower learners, where traditional forms can bypass learners' needs. Peer assessment includes students' involvement, not only in the final judgements made of students' works, but also in the prior setting of criteria and the selection of evidence of achievement (Bostock, as cited from Biggs, 1999; Brown, Rust, \& Gibbs, 1994).

One way in which learners can interact directly and help each other well is through peer reviews. This is what the paper deals with: the importance of peer review or peer feedback in this digital era. Direct interactions between or amongst students is an activity that can never be replaced with technology. Direct interactions can be facilitated, but not replaced, with technology. This was affirmed by Zacharias (2017) and Jati (2017). Both lecturers agree that direct interactions between or amongst students can be facilitated by technology. Jati (2017) mentioned,

Technology is a tool to help the teaching and learning process. Technology should be used to develop skills (discover, acquire, and communicate knowledge), as well as deepen learning possibilities through collaboration among schools and ideally collaboration worldwide. Only people who do not understand the role of technology think that technology "replaces" teacher-teacher or student-student interactions. (Jati, 2017).

Technology comes as an aid or means, not to replace teachers. These two lecturers' opinions coincide with each other. Direct interactions can be facilitated but not replaced by technology. Lecturers are there in the classroom to facilitate learning as well, so that it goes on as expected. Jati (2017) gave an example of how peer reviews can even be done 
across two countries. "Peer reviews in this era can be done wider in terms of scope (there are many middle schools in big cities that collaborate with overseas schools) and do projects together. In this setting, then peer reviews are done by using technology."

This paper presents descriptive data on Academic Writing students' opinions on peer reviews, one among other activities they had undergone in their course in Semester II of the 2015-2016 Academic Year. Male and female students' opinions are also analyzed to find different angles of how those different genders perceive the peer review process. Besides that, how interactions among learners can best be done directly is also revealed in this paper.

\section{E. Academic Writing}

Academic writing refers to all writing which is created for the purpose of study (Chin et al., 2012). All university students will be especially evaluated based on their writing, so writing skills are essential for students' academic success. Chan (2013) reinforced this idea by saying that when we write argumentative essays, our goal is to persuade others to adopt our view. We do that not by twisting the audience's arms, absolutely, but by putting forward convincing evidence, sensible reasoning, and effective rebuttals.

There are many students who do not like academic writing, because they think that it is very difficult. However, whether we like it or not, and whether we realize it or not, in our daily lives, we are all involved in some form of persuasion, both routine and accidental ones.

For examples, one may argue with one's friends or family members about who should be voted out of a reality TV show like Indonesian Idol, why we need to increase the amount of unlimited Internet access, or why an eight-hundredthousand-rupiah budget for a prom night gown is necessary. Examples of serious national debates include whether Indonesia ought to have a nuclear plant, whether the official retirement age should be raised to 75 years old, whether drug addicts should be given severe punishments, and many other arguments.

In academic writing, students will learn about the fundamentals of a good argument. They learn how to find mistakes, fallacies, or inconsistencies in others' arguments, so that they will not be easily deceived. They will also learn how to formulate their own arguments and influence or persuade others to agree with their opinions. Having clear ideas in an analysis, synthesis, and evaluation will help students maintain a good, strong stance with consistency and good reasoning.

\section{RESEARCH METHODOLOGY}

Altogether, there were 39 students whose opinions on peer reviews were used for this study. Eighteen students were from Academic Writing Group D, and the other 21 students were from another parallel class, Group E. These students took these classes in Semester II of the 2015-2016 academic year. At the end of the semester, all students had to write a journal on peer reviews. These students were classified as introvert, extrovert, visual, and auditory students. They had been classified into these four categories in the previous semester, based on questionnaires that they filled in.

The samples of this study were 2 classes of Academic Writing students who were purposively selected. Questionnaires were distributed one semester before the implementation of the research, that is, in Semester I, 20152016 to the population of Argumentative Writing, a kind of preparatory class for Academic Writing. Out of 102 students, 42 were chosen, 21 students in each class. One visual student, however, dropped the class in the first week. In both experimental and control groups, there were students of 2 different personality types, that is, introvert and extrovert, and 2 learning styles, auditory and visual.

There were 21 students in the experimental group, and 20 in the control group. This was because 1 student of the control group - dropped the class in the first week, since one requirement for the Academic Writing course could not be fulfilled. Altogether, there were 20 students for Group D (the control group), 6 introvert students, 5 extrovert students, 4 visual students ( 1 visual student dropped the class in the first week), and 5 auditory students. In Group E, the experimental group, there were 21 students: 5 introvert students, 6 extrovert students, 5 auditory students, and 5 visual students. However, for this study, two students did not return the peer review journals. Altogether, there were 39 students whose opinions were used for this paper, 12 female and 6 male students from Group D. While from Group E, there were 12 female and 9 male students from Group E.

In this research, only 39 students' opinions were used. Two students did not submit their journals. In this activity, students did peer reviews on their friends' introductory and body paragraphs. They were asked to assess each other's works, based on questions in a checklist. After doing this, they could continue with discussions in order to find similar perceptions about their opinions.

\section{RESULTS AND ANALYSIS}

\section{A. Students' Voices}

In this section, students' opinions about peer assessments are revealed. As previously mentioned, data was taken from 39 students' opinions which they detailed in their journals. These students' responses were divided into several sections according to their categorization. Both groups, Group D (control group) and Group E (experimental group) had a kind of activity called a peer review or peer assessment. 
In this study, students were given initials according to their alphabetical order, their type (Introvert, Extrovert, Auditory, Visual), and their group. Thus, Student AAD for example meant Student A with an auditory learning style, from Group D, whereas Student EIE for example, was Student E, an introvert, from Group E, and so on.

\section{B. Students in Group D}

From Group D (control group), students' opinions were categorized into several kinds, that is, positive opinions based on the usefulness and importance of peer reviews, negative opinions from a cynical student, no specific opinions, and positive opinions due to good teamwork. The data and perceptions of the students can be viewed in Table 1 .

The first category is students who thought positively about peer assessments from Group D. Falling into this category are Student AID (M), Student BID (F), Student DID (F), and Student EID (F). They were all introvert students. The second group was comprised of Student BED (F), Student CED (F), Student DED (F), and Student EED (F). These were extrovert students who also fell into this category. Next were auditory students. Student BAD (F), Student CAD (F), and Student DAD (M) belonged to this group. The last three participants were Student BVD (F), Student CVD (F), and Student DVD (F), who were visual students. The majority of students in this group showed positive perceptions towards peer assessments (14 students, or $70 \%$, out of 20 students).

These positive-thinking students thought that peer assessments or peer reviews are an important step in the process of writing. Student AID (M) for example, mentioned, "In a peer review I can correct, give comments, or give suggestions easily because I assess someone else's work. From having someone else review my work, I will know about the problems that I have in my essay. From his/her review, I can improve my essay and have some new ideas from the advice that my classmate gave" (Student AID's $7^{\text {th }}$ Journal, unedited). This student was a quiet one, but he was diligent in doing any assignments given to him.

A similar opinion came from Student DVD (F). She was an average student without outstanding achievement. For her, peer and lecturer feedback was very important. She expressed her opinions in her journal as follows:

Peer feedback and lecturer feedback is beneficial in the teaching and learning process. It gives students the opportunity to revise their work, for example, in an essay. Peer feedback and lecturer feedback will make students learn from something wrong in their work. It helps them to analyze the weaknesses of their work. (Student DVD's $7^{\text {th }}$ Journal)

It seems that this student realized the importance of peer feedback. Another student who was in line with her was Student CVD (F), who thought that it was fun and useful. "Overall, in my opinion, doing outline presentations and giving feedback is useful, helpful, and fun" (Student CVD's $7^{\text {th }}$ journal). Similar to Student DVD, this student was just an ordinary student. She realized the significance of peer and lecturer feedback for the improvement of her essay.

The second classification of opinion was the cynical one. As usual, some cynical opinions came from Student AVD (M). Student AVD was often "bitter" in his opinion. Born from a wealthy family with a good financial condition and good competence in English might make him feel somewhat better than his peers. He was disappointed with his peer student's assessment. He mentioned that he did not get any feedback in the content which he had wanted. These are his statements on it:

I honestly do not have any idea toward the feedback I got about my outline presentations. After that, I think peer assessment activity just so - so for me. There was nothing special there. I picked my partners randomly. The feedback I got rarely mentioned the content. Therefore, I simply concluded that I had to use simpler language in order to keep the readers in line with my ideas. (Student AVD's $7^{\text {th }}$ Journal)

This student might have belittled his peer students, feeling that he was much smarter than his friends, and he might have felt that he did not need anyone's help. This is an example of a typically over-confident student with too much pride in himself.

In this class, there were two students who did not give any specific opinion towards peer assessment; they were Student AAD (F) and Student CID (M). They just talked about what happened in the classroom without giving any perceptions on the peer review process.

The last category came from Student EAD (M) whose opinion was related with his peers. Student EAD thought that he liked having a peer review since he got a good partner. This student was another quiet one who did not talk a lot in class. Table 1 clarifies the students' perceptions and data about their gender and GPA. Table 1 contains information on introvert and extrovert students' data and perceptions. 
TABLE I.

SumMARY OF GROUP D STUDENTS' PERCEPTIONS TOWARDS PEER REVIEWS

\begin{tabular}{|c|c|c|c|}
\hline Student Initials & $\begin{array}{c}\text { Perceptions towards Peer } \\
\text { Feedback }\end{array}$ & GPA & Gender \\
\hline AID & + & 3.24 & M \\
\hline BID & + & 3.37 & $\mathrm{~F}$ \\
\hline CID & No opinion & 3.56 & $\mathrm{M}$ \\
\hline DID & + & 3.63 & $\mathrm{~F}$ \\
\hline EID & + & 3.30 & M \\
\hline BED & + & 3.80 & $\mathrm{~F}$ \\
\hline CED & + & 3.42 & $\mathrm{~F}$ \\
\hline DED & + & 3.22 & $\mathrm{~F}$ \\
\hline EED & + & 3.61 & $\mathrm{~F}$ \\
\hline AAD & No opinion & 3.47 & $\mathrm{~F}$ \\
\hline BAD & + & 3.63 & $\mathrm{~F}$ \\
\hline CAD & + & 3.26 & $\mathrm{~F}$ \\
\hline DAD & + & 3.56 & $\mathrm{M}$ \\
\hline EAD & $\begin{array}{c}+ \\
\stackrel{+}{(G o o d} \text { Partner) }\end{array}$ & 3.55 & M \\
\hline AVD & $\begin{array}{c}- \\
\text { (Cynical) }\end{array}$ & 3.76 & $\mathrm{M}$ \\
\hline BVD & + & 3.74 & $\mathrm{~F}$ \\
\hline CVD & + & 3.20 & $\mathrm{~F}$ \\
\hline DVD & + & 2.97 & $\mathrm{~F}$ \\
\hline
\end{tabular}

\section{Students in Group E}

Then in Group E, the opinions can be classified into four categories as well. They are positive responses (due to usefulness and importance), negative responses due to peers who were not nice to work with, positive responses (because of compatible peers), and negative responses due to the quantity of work which was too much.

The first category is positive responses due to the usefulness and importance of peer reviews. Falling into this category were Student AIE (F), Student EIE (M), Student BIE (M), and Student CIE (F), who were introvert students. The next were Student AEE (F), Student BEE (F), Student EEE (F), and Student EAE (M), who were extrovert students. The last group was comprised of Student BAE (F) and Student AVE (F), who were auditory students. Visual students were Student CVE (M), Student DVE (F), and Student EVE (F).

Student AIE, for example, mentioned that peer assessment made her practice to give meaningful feedback to her classmate, so that her classmate could make a more interesting essay. Student CIE also shared a similar idea. She mentioned, "In a peer assessment, I can compare my essay with my classmate's ... we can share the information or knowledge we have ..." These two girls were quiet and silent most of the time, but they always did all their assignments enthusiastically.

In the second category, there were students who thought negatively or had negative opinions towards peer reviews. Their bitter experiences were triggered by 'problems' with their peers' personalities. Student FEE (F), for example, had an unpleasant experience with her peer. Her peer was so lazy to seriously review her essay that this peer just pretended. Below is her statement:

I think it is very advantageous for us because it can help improve our essays, but I had a bad experience when I did a self-assessment for the first draft. The classmate who got my essay was lazy to read my essay, so when she graded my essay she only asked me whether my essay was appropriate or not with the questions in the assessment. Actually, I was very disappointed because she was not objective in grading my essay. In my opinion, if she does it again, she is wrong and it will be disadvantageous for her friends because they cannot improve their essays if the way to give the grade is wrong. (Student FEE's $7^{\text {th }}$ Journal)

Student FEE was a diligent one with good ideas. However, she often felt emotional whenever she got partners who were not in line with her expectations. In the same boat as Student FEE were Student DEE (M) and Student AAE (F).

Student DEE (M) had a somewhat similar experience related to his feelings. He felt uneasy and uncomfortable to give comments and criticize his peers. He stated, "Doing the peer assessment on someone's writing is also a little hard to decide whether my comments are appropriate enough or not." This student was actually a nice and diligent one. Being sensitive to others' feelings made him feel bad when he had to criticize his friends' works.

A similar thing was experienced by Student AAE (F), though the case was different. Student AAE mentioned that she sometimes did not understand what her peer meant. Difficulty in understanding her peer's statements was a big problem for her.

Sometimes when I did not understand what Student BIE meant in his essay, I would ask him or another classmate, since I could not assess it based on my own understanding. He did enough good work, although it was not complete yet. 
For everything above, I felt good after the self- and peer assessments; I could improve my weaknesses to be better. (Student AAE's $7^{\text {th }}$ Journal)

The next category was students who had good experiences in reviewing their peers' work. Their pleasant experiences were because of good peers. Included here were Student CEE (M) and Student DAE (M). Stated below is Student CEE's opinion:

I like the idea of peer-assessment. The first time I had to review my classmate's work was fun, because she is smart and I learned a lot from it. By doing peer-assessment, we are not only helping our classmates to work with their assessments, but we also can learn something from them. For example, we can see the mistakes that are usually made in our classmates' works, how they create sentences using certain words, what the proper format for writing is, how to use proper punctuation, etc. (Student CEE's $7^{\text {th }}$ Journal).

Working with a smart classmate really made him happy and motivated. Similar to him was Student DAE (M). These two boys felt lucky since they got smart classmates who made them feel comfortable to work with. He stated that,

I exchanged my final paper with my classmate, Student DVE. We are friends, but not really close, so I chose her to work with me. And I think she thinks more critically than me. Hence, I hoped she could find many errors that I made in my final paper. When I did this assessment, I also did think critically about her final paper, but I was surprised that I found her final paper to be almost perfect (My view)." (Student DAE's $7^{\text {th }}$ Journal, unedited).

The last category was an opinion which stated that this peer reviewing work was too much for the students. They were Student CAE (F) and Student BVE (F). Here is what they stated in their journals. They felt burdened and overloaded with this task.

Self-assessment and peer assessment are good to assess our own work or our classmates' work. We can learn from our own mistakes and our friends' mistakes. But some content in the self-assessment or peer assessment is too complicated and confusing. Some content made the self-assessment or peer assessment not effective enough for students. For example, we have to read all the paragraphs (which is so many pages) and correct the words one by one. It will take much time. (Student CAE's $7^{\text {th }}$ Journal).

These two students felt burdened with the peer review assignment. For them, the quantity of work was too much, even though they admitted the advantages of doing a peer review. It can be seen further, even though students' opinions varied, in general they admitted the usefulness and importance of doing peer assessments. Similar to Student CAE's statement, Student BVE also complained, "I think it is more difficult than doing a self-assessment, because I have to read my partner's whole essay and give back on it as well."

Table 2 shows a summary of the students' perceptions towards doing peer reviews.

TABLE II.

Summary OF GRoup E STUdENTS' PERCEPTIONS TOWARdS PEER REVIEWS

\begin{tabular}{|c|c|c|c|}
\hline Student Initials & $\begin{array}{c}\text { Response towards Peer } \\
\text { Review }\end{array}$ & GPA & Gender \\
\hline AIE & + & 3.42 & $\mathrm{~F}$ \\
\hline BIE & + & 3.73 & M \\
\hline CIE & + & 3.46 & $\mathrm{~F}$ \\
\hline DIE & + & 3.35 & M \\
\hline EIE & + & 3.22 & M \\
\hline AEE & + & 3.50 & $\mathrm{~F}$ \\
\hline $\mathrm{BEE}$ & + & 3.66 & $\mathrm{~F}$ \\
\hline CEE & + & 3.65 & $\mathrm{M}$ \\
\hline DEE & - & 3.70 & M \\
\hline EEE & + & 3.22 & $\mathrm{M}$ \\
\hline FEE & - & 3.22 & $\mathrm{~F}$ \\
\hline $\mathrm{AAE}$ & - & 3.29 & $\mathrm{~F}$ \\
\hline BAE & + & 3.46 & $\mathrm{~F}$ \\
\hline $\mathrm{CAE}$ & - & 3.29 & $\mathrm{~F}$ \\
\hline DAE & + & 3.54 & M \\
\hline EAE & + & 2.96 & M \\
\hline AVE & + & 3.78 & $\mathrm{~F}$ \\
\hline BVE & - & 3.35 & $\mathrm{~F}$ \\
\hline CVE & + & 3.23 & M \\
\hline DVE & + & 3.86 & $\mathrm{~F}$ \\
\hline EVE & + & 3.53 & $\mathrm{~F}$ \\
\hline
\end{tabular}


From this research, it can be concluded that the majority of the students $(85.37 \%)$ had positive perceptions towards the peer review process. Only six students perceived peer reviews negatively due to unpleasant feelings in criticizing their classmates or due to peers who were uncooperative.

In dealing with gender issues, it was perceived that in both groups, out of 24 female students, three gave negative opinions towards peer reviews. This means that $12.5 \%$ of female students perceived peer reviews negatively. While out of 15 students, only two male students gave negative opinions. This means that $13.33 \%$ of male students perceived peer reviews negatively. This can further be interpreted that among both female and male students, the percentage of positive and negative thinkers was almost the same.

The next conclusion is that female students are subject to stress. As discussed previously in the theories, women are more subject to distress. Men and women are created differently physically, mentally, and cognitively, that is, in their way of thinking. This study therefore reveals that in doing peer reviews, more male students enjoyed this activity than their female counterparts.

In this piece of research, for example, some female students were distressed. Student FEE (F) felt emotional because she had an unpleasant experience with her peer. Her peer was so lazy to seriously review her essay that this peer just pretended. Another student under the same umbrella was Student AAE. She mentioned that she sometimes did not understand what her peer meant. Difficulty in understanding her peer's statements was a big problem for her. It made her confused and unable to enjoy the activity. There were two other students who felt emotional during this activity. They were Student CAE (F) and Student BVE (F). They felt burdened and overloaded with this task. These are examples of how female students are more easily distressed by their environment, like peers and the tasks they had to complete. Unpleasant moods to a certain extent, may lead to a lack of motivation and in turn, this can demotivate the process of language learning.

When dealing with gender differences, both in attitudes and emotions like this, lecturers should be neutral, but keep directing all the students to put aside emotional or psychological disturbances that might trigger unpleasant things in doing any assignment given. For future researchers, it is recommended that they investigate the effects of lecturers' gender on students' reactions or students' performance in the classroom.

This piece of research hopefully gives enlightenment for other lecturers in a way, so that they become more aware of their students' gender differences in the classroom. Lecturers thus can take wise actions when dealing with issues related to gender in the classroom. Just as what Jati (2017) mentioned about equality among men and women in this digital era, everybody should get equal opportunities: "The digital world and "non-digital" world are equal in terms of justice and equality. Everyone, anybody will have the same opportunity to take part." It is not the time to ask what men or women can do, but what everybody can contribute.

\section{ACKNOWLEDGEMENTS}

Special appreciation is given to the Indonesian Ministry of Research, Technology, and Higher Education (Kemenristek Dikti Indonesia), which had funded my Doctoral Research through a PDD Research Grant, in 2016. My gratitude also goes to Academic Writing Students of Group D and E, Semester II, 2015-2016.

\section{REFERENCES}

[1] Bostock, S. (2017). Student Peer Assessment. The Higher Education Academy. Retrieved January 30,2017 from https://www.cs.auckland.ac.nz/courses/compsci747s2c/lectures/paul/Student_peer_assessment_-_Stephen_Bostock.pdf.

[2] Brown, D. (2001). Teaching by Principles: An Interactive Approach to Language Pedagogy. SF: Longman

[3] Brown, M. (2017). What Are the Differences between Male and Female Thinking Patterns? Retrieved June 22, 2017 from https://www.quora.com/What-are-the-differences-between-male-and-female/.

[4] Carleton.Edu. (2017). Student-Student Classroom Interactions. Retrieved June 22, 2017 from http://serc.carleton.edu/NAGTWorkshops/certop/imp_ssi.html.

[5] Carson, L. (2001). Gender Relations in Higher Education: Exploring Lecturers' Perceptions of Student Evaluations of Teaching. Research Papers in Education 16(4) 2001, p.338.

[6] Crowley, B. (2014). What Digital Literacy Looks Like in a Classroom. Retrieved March 4, 2016 from http://mobile.edweek.org/c.jsp?cid=25919971\&bcid=25919971\&rssid=25919961\&item=http\%3A\%2F\%2Fapi.edweek.org\%2 Fv1\%2Ftm\%2F\%3Fuuid\%3DF3E619C6-5EBF-11E4-BB57-BDA3B3743667.

[7] Department of Teacher Education, University of Helsinki, Finland. (2015). Innovative Schools: Teaching and Learning in the Digital Era. Workshop Documentation.

[8] Gurney, J. (2013). Digital Literacy 'as Important as Reading and Writing'. Retrieved March 4, 2016 from http://www.telegraph.co.uk/education/educationopinion/10436444/Digital-literacy-as-important-as-reading-and-writing.html.

[9] Jati, G. (2017, June 23). Online Interview by Listyani/Interviewer. Indonesian Readiness in Facing the Digitation in Education. Achieved in Facebook Messenger.

[10] Kennedy, G. (2006). Peer Assessment in Group Projects: Is It Worth It? School of Information Technologies. The University of Sydney. NSW. Retrieved on $\quad$ January $30, \quad 2017$ from https://www.google.com/url?sa=t\&rct=j\&q=\&esrc=s\&source=web\&cd=1\&cad=rja\&uact=8\&ved=0ahUKEwjzwqv416XcAhU JWX0KHduDCYwQFggoMAA\&url=http\%3A\%2F\%2Fcrpit.com\%2Fconfpapers\%2FCRPITV42Kennedy.pdf\&usg=AOvVaw 0QKqVSa0anLG-kgsOwcuPq.

[11] McNutt, R. (2016). Quotes about Digital Age. Retrieved March 4, 2016 from http://www.goodreads.com/quotes/tag/digital-age. 
[12] Penaflorida, A. (2002). "Non-traditional Forms of Assessment and Response to Student Writing" in J. C. Richards and Willy A. Renandya (Eds.). Methodology in Language Teaching. Cambridge University Press (CUP).

[13] Soefijanto, T. A. (2015). Digital Literacy: A Growing Demand. The Jakarta Post. Retrieved March 4, 2016 from http://m.thejakartapost.com/news/2015/06/03/digital-literacy-a-growing-demand.html.

[14] Sydelnykov, V. (2015). 13 Real Differences between Men and Women. Retrieved June 22, 2017 from http://thoughtcatalog.com/lorenzo-jensen-iii/2015/06/13-real-differences-between-men-and-women

[15] Tucker, R. (2013). "Sex Does Not Matter: Gender Bias and Gender Differences in Peer Assessments of Contributions to Group Work." Journal of Assessment and Evaluation in Higher Education. Vol. 39, No. 3, 2014. Retrieved August 15, 2017 from http://www.tandfonline.com.

[16] Ur, P. (1999). A Course in Language Teaching. Cambridge University Press (CUP).

[17] Wehr-Flowers, E. (2006). "Differences between Male and Female Students' Confidence, Anxiety, and Attitude toward Learning Jazz Improvisation.” Journal of Research in Music Education, Vol. 54, No. 4, (Winter, 2006), pp. 337-349 Published by: MENC: The National Association for Music Education.

[18] Wellein, M. G., Ragucci, K. R., \& Lapointe, M. (2009). Instructional Design and Assessment: A Peer Review Process for Classroom-Teaching. American Journal of Pharmaceutical Education, 73 (5). Article 79.

[19] Zacharias, H. (2017, May 22). Personal Interview by Listyani/Interviewer. Digitation on Education. Salatiga.

[20] 2knowmyself.com. (2017). Psychological Differences between Men and Women. Retrieved June 22, 2017 from https://www.2knowmyself.com/psychological_differences_between_men_and_women.

Listyani is a lecturer at the English Language Education Study Program, Faculty of Language and Arts (FLA), Universitas Kristen Satya Wacana (UKSW) Salatiga, Indonesia. She has been teaching there since March 1999. In August 2017, she got her Doctorate Degree (Dr.) from State University of Semarang (UNNES) Indonesia, majoring in English Language Education. She has published a textbook on Academic Writing, and is productive in publication of research articles, both in national and international journals. 